\title{
Pencitraan (Branding) dan Promosi Desa Wisata Pengkol, Kecamatan Ngunter, Kabupaten Sukoharjo, Jawa Tengah
}

\author{
Tular Sudarmadi \\ Fakultas Ilmu Budaya, Universitas Gadjah Mada \\ Korespondensi: tular_s@ugm.ac.id
}

\begin{abstract}
Pengkol Village Community service in 2020 is a continuation of the development of Pengkol Village, Nguter District, Sukoharjo Regency, Central Java as a tourism village, managing from a communitybased tourism point of view. Actually, the first Community service was carried out in the Pengkol village in 2017. A tourism potential identification program in Pengkol Village successfully conducted. The results show that Pengkol Village has the potential to be developed as a community-based tourism village. Furthermore, in 2018 to 2019 Community Service in this village is continued to form a community-based tourism management institution. The results of the program are the establishment of Pokdarwis village institution. This program after being written, was successfully defended as an undergraduate thesis by an undergraduate student from the Tourism Program. Since the institution is functioning, it is time to arrange the third session of Community service in Pengkol village. A branding and promotion of the Pengkol Tourism Village is designed and will advertise via social media. While COVID-19 plague occurs, Pokdarwis works on video making of Pengkol Village tourism branding and promotion. Since, COVID-19 protocol banned people from traveling and to flock, an online communication was set up. Moreover, the making of the video will be managed by Pokdarwis. On the other hand, the Tourism Program made a script and designed the Pengkol Tourism Village logo. Finally, in October 2020 the Pengkol Tourism Village logo was successfully created. A Jargon 'Tani Minantaka Tourism Village is Near in the Eyes and sticky to the Heart" is also launched. In addition, video branding and video promotion of Pengkol Tourism Village were successfully made, which were then uploaded on social media Instagram, Facebook of the Pokdarwis Desa Wisata Pengkol.
\end{abstract}

Keywords: community service; Pengkol Tourist Village; video branding; video promotion

\begin{abstract}
Abstrak
Pengabdian kepada masyarakat di Desa Pengkol tahun 2020 merupakan kelanjutan dari pengembangan Desa Pengkol, Kecamatan Nguter, Kabupaten Sukoharjo, Jawa Tengah sebagai desa wisata yang pengelolaannya berbasis masyarakat. Pengabdian kepada masyarakat di desa tersebut diawali pada tahun 2017 dengan program identifikasi potensi kepariwisataan di Desa Pengkol. Hasil identifikasi menunjukkan bahwa Desa Pengkol sangat potensial untuk dikembangkan sebagai desa wisata berbasis masyarakat. Selanjutnya, pada tahun 2018 hingga 2019, pengabdian kepada masyarakat di desa ini diprogramkan untuk membentuk kelembagaan pengelolaan pariwisata berbasis masyarakat. Hasil pendampingan tersebut menghasilkan keluaran berupa skripsi S-1 dari mahasiswi pendampingan program. Berdasarkan dengan dibentuknya Pokdarwis Desa Pengkol yang berfungsi untuk mengelola dan mengembangkan program kepariwisataan berbasis masyarakat di desa ini, program pengabdian kepada masyarakat yang ketiga lebih bersifat melakukan pendampingan dan bertindak sebagai fasilitator dalam
\end{abstract}


menyiapkan program pencitraan dan promosi Desa Wisata Pengkol. Selama tiga bulan dalam pelaksanaan pengabdian kepada masyarakat, yang masih terkendala wabah COVID-19 berhasil melibatkan Pokdarwis secara aktif dalam program pencitraan dan promosi. Adanya wabah COVID-19 disiasati dengan pendampingan online, sedangkan pembuatan video akan dikelola oleh Pokdarwis. Adapun program studi berperan dalam membuat naskah dan merancang logo Desa Wisata Pengkol. Pada Oktober 2020, berhasil dibuat logo Desa Wisata Pengkol dan pencitraan "Desa Wisata Pengkol Tani Minantaka: Dekat di Mata Lekat di Hati". Selain itu, berhasil pula dibuat satu video pencitraan dan satu video promosi Desa Wisata Pengkol yang kemudian diunggah di media sosial Instagram Facebook Pokdarwis Desa Wisata Pengkol.

Kata kunci: pengabdian kepada masyarakat; Desa Wisata Pengkol; video branding; video promosi

\section{Pendahuluan}

Akhir-akhir ini, para ahli pariwisata menyarankan industri pariwisata alternatif yang mengakomodasi pengelolaan industri pariwisata berskala kecil (small-scale tourism), yang bersifat lebih demokratis karena melibatkan masyarakat lokal dalam pengembangan dan pengelolaannya (community based tourism) sehingga program-programnya berkelanjutan (sustainable) dan berupaya untuk mengentaskan kemiskinan masyarakat lokal (proo-poor tourism) (Holden 2005:122-123; Scheyvens, 2015; Jamal dan Dredge, 2015). Contoh bentuk pengembangan dan pengelolaan pariwisata berbasis masyarakat antara lain berupa pelibatan komunitas sepeda Victoria, Australia dalam jejaring desa wisata yang dikoordinasi oleh Kota Koroit di Victoria Barat, Australia berhasil menjaring 200,000 Aus \$ di setiap desa yang dilewati rute sepeda gembira tersebut. Selain itu, suasana festival dan peliputan acara di media sosial berhasil mempromosikan desa-desa wisata yang terlibat dalam acara tersebut tanpa mengeluarkan ongkos sama sekali (Beeton 2006:140). Pendampingan oleh Lembaga Swadaya Masyarakat The Kurihara Tourism Network terhadap komunitas desa-desa lokal di kawasan Kurihara, Jepang Utara melalui proyek pelibatan wisatawan dan penduduk lokal bersama-sama merasakan pengalaman membuat kuliner dan melakukan kegiatan bertani sesuai dengan cita rasa dan peralatan tradisional yang diwariskan secara turun temurun. Hasil akhir proyek menunjukkan adanya penambahan penghasilan selain dari penghasilan pokok, penguatan identitas warga lokal, dan menumbuhkan perasaan puas dan nyaman, baik bagi wisatawan maupun warga lokal (Ohe, 2020:267-276).

Model pengelolaan seperti disebutkan sebelumnya dapat diterapkan untuk pengembangan pengelolaan industri pariwisata berskala kecil, khususnya dalam kerangka pariwisata berbasis masyarakat di Desa Pengkol. Konsep pariwisata berbasis masyarakat sesuai untuk diterapkan antara lain karena melibatkan partisipasi seluruh warga desa, kepemilikan oleh seluruh warga desa, meningkatkan rasa kebanggaan, meningkatkan kesejahteraan, dan menghormati perbedaan budaya serta memanusiakan wisatawan (Suansri, 2003:12).

Desa Pengkol secara administratif terletak di Kelurahan Pengkol, Kecamatan Nguter, Kabupaten Sukoharjo bagian paling ujung yang berbatasan dengan Kabupaten Wonogiri. Saat ini, penduduk Desa Pengkol mencapai 49.212 jiwa dengan luas wilayah desa sebesar 366,3 ha, yang sebagian besar tanahnya merupakan sawah basah beririgasi. 
Secara keseluruhan, sawah basah di Desa Pengkol mendapat air dari Bendung/Dam Colo, salah satu pintu air utama dari waduk Gajah Mungkur. Keberadaan Dam Colo tidak hanya sebatas sumber pengairan sawah basah, tetapi juga sebagai tambahan penghasilan warga desa dari usaha menangkap ikan dan menjual peralatan penangkap ikan. Meskipun demikian, tingkat kesejahteraan dan taraf pendidikan penduduk Desa Colo masih memprihatinkan. Keadaan semacam ini disebabkan oleh pendapatan yang diperoleh dari hasil pertanian sawah basah dan perikanan tidak cukup untuk memenuhi kebutuhan hidup dan menyekolahkan anak-anak mereka. Akibatnya, sebagian besar generasi muda merantau ke luar desa untuk bekerja di pabrik-pabrik di sekitar kawasan Sukoharjo dan Solo, bahkan ada pula yang menjadi migran buruh di negara Malaysia, Singapura, Hongkong, dan Arab Saudi.

Berdasarkan konsep pariwisata berbasis masyarakat yang mensyaratkan program pengembangan dan pendampingan secara berkelanjutan terhadap warga lokal pemilik aset atraksi wisata, sampai saat ini, potensi pariwisata Desa Pengkol belum pernah diobservasi dan diteliti sehingga sangat memungkinkan untuk dilakukan program pengembangan serta pengelolaan Desa Pengkol sebagai desa wisata melalui program pengabdian kepada masyarakat dalam beberapa tahapan. Atas dasar hal tersebut, sejak tahun 2017, pelaksanaan program pengabdian kepada masyarakat di Desa Pengkol dimulai dengan melakukan identifikasi potensi atraksi wisata yang dapat dikembangkan dan dikelola oleh penduduk Desa Pengkol. Hasil akhir program kegiatan tersebut berupa identifikasi terhadap tiga kelompok jenis atraksi wisata dan ketersediaan komponen aksesibilitas serta amenitas yang menunjang pengembangan Desa Pengkol sebagai daerah tujuan wisata (Sudarmadi, 2018).

Tahap kedua program pengabdian kepada masyarakat di Desa Pengkol dilakukan sejak tahun 2018 hingga 2019. Kegiatan program difokuskan pada pembentukan kelembagaan pengelola pariwisata berbasis masyarakat di desa tersebut. Kasus pengelolaan atraksi wisata dan kasus-kasus lain yang mengabaikan keberadaan kelembagaan dalam pengelolaan desa wisata sehingga berakhir dengan konflik sosial, budaya, lingkungan alam, dan ekonomi dijadikan sebagai acuan serta bahan perbandingan dalam membentuk, menyusun, dan menyempurnakan struktur organisasi kelembagaan di Desa Pengkol. Setelah melalui proses pendampingan, pemetaan pemangku kepentingan, diskusi terpumpun (focus group discussion) tentang keinginan dan harapan para pemangku kepentingan, khususnya yang berkaitan dengan pengembangan dan pengelolaan pariwisata berbasis masyarakat di Desa Pengkol, terbentuklah kelembagaan yang akan difungsikan untuk mengelola kegiatan pariwisata berbasis masyarakat di desa tersebut. Kelembagaan tersebut berbentuk kelompok sadar wisata (pokdarwis) dengan model bottom-up dan diresmikan pada 12 Januari 2020 (Yanti, 2020).

Secara keseluruhan, dua program yang telah dilakukan merupakan adaptasi dari konsep The Mountain Institute (2000:17) tentang pemberdayaan dan pendampingan masyarakat melalui potensi kepariwisataan yang dimiliki oleh suatu kawasan. Program yang dilakukan tidak dapat dilakukan dalam satu kegiatan, tetapi harus bertahap sebagaimana terlihat dalam bagan pada gambar 1 .

Apabila dicermati, program identifikasi potensi atraksi wisata yang dikelola dan dikembangkan oleh penduduk Desa Pengkol merupakan tahap awal dalam bagan ini, yaitu observasi potensi serta penetapan visi dan misi, sedangkan program pembentukan 


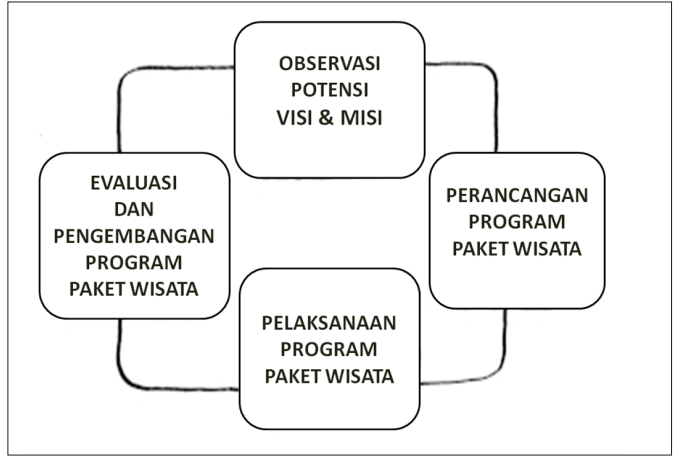

Gambar 1. Tahap-tahap pemberdayaan dan pendampingan masyaakat melalui potensi kepariwisataan Sumber: adaptasi dari konsep The Mountain Institute (2000:17)

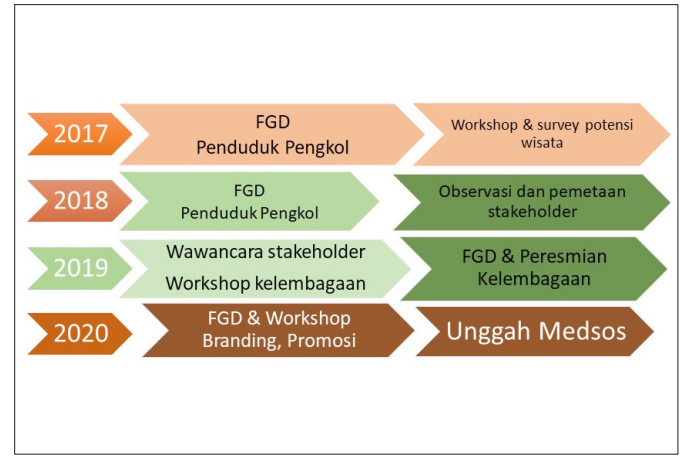

Gambar 2. Bagan alir tahapan pengabdian kepada masyarakat yang sudah dilakukan pada 2017, 2018, dan 2019 dan akan kembali diterapkan pada 2020. Sumber: data pribadi

organisasi kelompok sadar wisata di Desa Pengkol merupakan tahap selanjutnya, yaitu perancangan program paket wisata. Demikian juga program ketiga yang dirancang untuk pembuatan paket wisata, pencitraan (branding), dan promosi Desa Wisata Pengkol masih belum beranjak dari tahap perancangan program paket wisata. Walaupun masih dalam tahap yang sama, program ketiga lebih memfokuskan kegiatannya pada upaya pemasaran atraksi wisata di desa tersebut. Berikut disajikan bagan alir tahapan pengabdian kepada masyarakat yang sudah dilakukan pada tahun 2017 dan 2018-2019 serta yang akan dilakukan pada tahun 2020 .

\section{Permasalahan Lapangan}

Saat ini, kelembagaan untuk mengelola kegiatan kepariwisataan di Desa Pengkol yang berupa organisasi kelompok sadar wisata sudah terbentuk. Di lain pihak, keberadaan suatu lembaga tanpa adanya kegiatan dapat menimbulkan perasaan frustrasi dan keengganan untuk menjaga keberlanjutan organisasi tersebut. Selain itu, dengan dilakukannya pembuatan pencitraan (branding) dan promosi melalui media sosial akan menjadikan Desa Pengkol lebih dikenal khalayak luas sebagai atraksi desa wisata yang dapat dikunjungi oleh para wisatawan. Program ini sekaligus merupakan pemasaran awal agar Desa Pengkol dikunjungi oleh wisatawan. Di lain pihak, kunjungan tersebut akan menghasilkan keuntungan ekonomi, peningkatan pendapatan, dan mengurangi arus penduduk usia kerja di Desa Pengkol yang sebagian besar bermigrasi ke perkotaan untuk mencari pekerjaan.

Meskipun demikian, baik pengurus maupun anggota Pokdarwis belum memiliki kemampuan membuat gagasan (konsep), keterampilan, dan dana untuk melakukan pembuatan video pencitraan serta promosi Desa Wisata Pengkol. Agar warga Desa Pengkol menyadari pentingnya pencitraan dan promosi desa wisata, program pendampingan, pelatihan, dan pemberdayaan untuk mengemas pencitraan serta promosi perlu segera dilakukan. 


\section{Relevansi Program}

Kegiatan pengabdian kepada masyarakat tahap ketiga ialah melakukan pendampingan dan pemberdayaan terhadap para pengurus dan anggota kelompok sadar wisata Desa Pengkol, khususnya dalam pencitraan serta promosi wisata Desa Pengkol. Saat ini, dengan merebaknya wabah Covid-19, banyak warga desa yang bekerja di kota-kota besar kembali ke Desa Pengkol dan kehilangan mata pencahariannya. Di sisi lain, kepulangan mereka juga akan menimbulkan masalah karena di Desa Pengkol tidak terdapat lapangan pekerjaan bagi para migran ini. Pelatihan dan pendampingan pencitraan serta promosi wisata selain dapat memunculkan optimisme adanya lapangan pekerjaan sesudah wabah berakhir dan menghindarkan konflik sosial karena pengangguran juga dapat mencegah keinginan mereka untuk kembali menjadi pekerja informal di kota-kota besar.

Pada dasarnya, para pengurus dan anggota kelompok sadar wisata Desa Pengkol yang sudah mendapat pelatihan, pendampingan, dan praktik pembuatan video pencitraan dan promosi diharapkan akan menjadi pelopor untuk membagikan pengetahuan yang diperoleh dalam program pembuatan video kepada segenap warga desa yang menginginkannya. Peran para pemangku kepentingan (pengurus desa, Badan Permusyawaratan Desa (BPD), Badan Usaha Desa, Dinas Pendidikan dan Kebudayaan (Bidang Pariwisata), Pengelola Bendung Colo, pedagang kios di bantaran Bendung Colo, Kapolsek dan Koramil, para pengusaha kuliner, dan pemuka masyarakat dalam program ini tidak boleh diabaikan. Para pemangku kepentingan ini dapat dijadikan target sasaran karena mereka memiliki kepentingan bersama dalam pengelolaan sumber daya atraksi wisata yang berkelanjutan, baik yang berupa kepentingan bisnis, penguasaan sumber daya alam, sosial dan budaya, hukum serta keamanan, maupun otoritas di bidang pengelolaan kepariwisataan Desa Pengkol. Ketidakpahaman mereka terhadap proses dan tahap pengembangan serta pengelolaan Desa Wisata Pengkol dapat memungkinkan terjadinya konflik dan perpecahan di kemudian hari.

\section{Pendekatan Pelaksanaan Program}

Pada umumnya, masyarakat beranggapan bahwa kegiatan pengabdian kepada masyarakat bukan merupakan kegiatan ilmiah, melainkan kegiatan untuk memberikan pelayanan jasa kepada masyarakat. Anggapan ini sebenarnya tidak tepat, mengingat ada juga kegiatan pengabdian kepada masyarakat yang merupakan campuran antara pelayanan jasa dan keilmuan. Demikian juga kegiatan pengabdian kepada masyarakat tahap ketiga ini merupakan bentuk pelayanan jasa (pendampingan dan konsultasi) serta keilmuan di bidang pariwisata berbasis masyarakat, khususnya pemasaran di tahap pencintraan dan promosi Desa Wisata Pengkol. Sebagai bukti, pengabdian kepada masyarakat di Desa Pengkol tahap ketiga ini mengaplikasikan teori tentang pencitraan dan promosi sebagaimana dikemukakan dalam landasan teori dan metode berikut.

\section{Landasan Teori Pencitraan (Branding) dan Promosi}

Peninjauan terhadap Desa Pengkol menunjukkan bahwa pemangku kepentingan dan warga desa menginginkan desa tersebut dijadikan desa wisata berbasis masyarakat dalam pengelolaannya. Hal ini berarti Desa Wisata Pengkol akan dijadikan produk yang dipasarkan ke masyarakat luas. Produk barang dan jasa tersebut diharapkan dapat 
dihasilkan dari industri wisata yang dikelola secara keseluruhan oleh warga desa. Sesuai dengan dalil ekonomi, suatu produk akan diminati jika ada permintaan (demand) dari peminat yang akan mengonsumsinya. Dalam hal ini, jika permintaan banyak dan pasokan produk sedikit, harga produk menjadi mahal. Sebaliknya, jika permintaan sedikit dan pasokan produk banyak, harga produk menjadi murah. Melalui proses pemasaran permintaan dan pasokan akan dijembatani dengan pengelolaan dan pengorganisasian hubungan yang saling memberi keuntungan antara permintaan dari konsumen dan pasokan dari produsen. Dengan kata lain, pemasaran merupakan proses yang meliputi penciptaan, penawaran, dan pelayanan produk serta jasa berdasarkan nilai-nilai sosial, budaya, dan ekonomi yang terkandung dalam produk tesebut. Di lain pihak, konsumen akan menginformasikan nilai-nilai yang mereka inginkan dalam produk tersebut. Proses timbal balik semacam ini akan menjalin hubungan yang erat dan kuat antara produsen dan konsumen (Pike, 2008:26; Kotler dan Keller 2016:11—12; Armstrong dkk., 2017:5-7).

Dalam rangka menginformasikan nilai-nilai produk yang dipasarkan, produsen akan melakukan pencitraan terhadap produknya. Pada dasarnya, pencitraan (branding) merupakan upaya produsen untuk memberikan identitas pada produknya. Tidak cukup hanya sebatas pemberian nama serta logo, tetapi visi dan misi produsen terhadap produk tersebut harus termuat. Selain itu juga terkandung nilai-nilai sosial, budaya, dan ekonomi dari konsumen yang akan dijadikan sebagai target pasokan produk serta menjalin hubungan komunikasi dengan konsumen. Pencitraan produk yang berhasil akan memberikan gambaran kepada konsumen tentang visi dan misi yang ingin dilekatkan oleh produsen pada produk tersebut, posisi produk tersebut terhadap produk sejenis, konsumen apa yang disasar, dan produk tersebut lekat dalam ingatan konsumen (Morgan dkk., 2004:3—5; Pike, 2004:69-75; Pike, 2008:174-175; Tasci, 2011:113-119; Armstrong dkk., 2017:322 —329).

Pencitraan bagi produk Desa Wisata Pengkol mutlak dilakukan mengingat jumlah desa wisata, baik yang aktif, sekadar nama hasil bentukan pemerintah, tidak dikelola, maupun bangkrut di seluruh Indonesia sangat banyak. Promosi terhadap karakter khas Desa Wisata Pengkol akan memberikan informasi lengkap yang menjelaskan perbedaannya dengan desa wisata lain di seluruh Indonesia. Keuntungan lain yang diperoleh ialah untuk menempatkan posisi desa wisata tersebut sesuai dengan minat (demand) para wisatawan yang menyukai produk semacam ini.

Kemajuan teknologi pada abad ke-21 memengaruhi penggunaan media promosi bagi pencitraan Desa Wisata Pengkol. Penemuan Web 2.0 berangsur-angsur menggantikan media brosur, surat kabar, majalah, radio, dan televisi dengan perangkat lunak yang mengakomodasi sumber informasi terbuka (sosial media). Jika sebelumnya promosi lebih bersifat searah (dari pihak yang memberi informasi tanpa memberi kesempatan kepada penerima informasi untuk langsung memberikan komentar, tanggapan, dan saran), aplikasi Web 2.0 memberikan fasilitas bagi penggunanya untuk mengirimkan gagasan, pengetahuan, dan informasi, baik secara tulisan (verbal), foto, maupun video (visual). Sebaliknya, pengguna yang menerima informasi dapat seketika (instant) memberikan tanggapan. Hal ini menyebabkan terjadinya pertukaran informasi yang terus-menerus, terbarui (update), dan melibatkan partisipasi yang tidak saja bersifat individu, tetapi dapat meluas ke kelompok dan masyarakat umum. Saat ini, berbagai aplikasi berbasis 
Web 2.0 yang memungkinkan sebagai sarana komunikasi di media sosial antara lain YouTube, Instagram, Facebook, Twitter, WhatsApp, Line, Tripadvisor, Virtual Tourist (Cooke dan Buckley, 2008:270_275; Sigala, 2015:7-9; Minazzi, 2015:2—7). Pemilihan media sosial berbasis Web 2.0 untuk pencitraan dan promosi Desa Wisata Pengkol juga berprinsip bottom up karena terjalin komunikasi interaktif antara wisatawan peminat dan pengelola produk wisata, komunikasi terus terbarui dan berkelanjutan, komunikasi juga bersifat demokratis karena, baik pengelola wisata maupun wisatawan dapat mengunggah informasi dan mendiskusikan bersama, memangkas ongkos promosi karena tidak harus mencetak brosur, surat kabar, televisi, dan radio serta tidak harus memberikan persentase pendapatan kepada biro travel, pemandu wisata, dan tidak harus membayar jasa kepada penyedia jasa media sosial (Cooke dan Buckley, 2008:276—288; Sigala, 2015:7; Minazzi, 2015:2).

\section{Metode Penerapan Teori Pencitraan (Branding) dan Promosi}

Penerapan teori tentang pencitraan dan promosi dalam kegiatan pengabdian kepada masyarakat di Desa Pengkol bukan dimaksudkan untuk membuktikan hipotesis tentang diterima atau ditolaknya teori tersebut. Keadaan semacam ini didukung oleh hasil observasi yang menunjukkan bahwa kegiatan promosi dan pemasaran belum dilakukan, tetapi baru sampai pada tahap pendirian kelembagaan Pokdarwis Desa Wisata Pengkol. Sesuai dengan kondisi aktual di lokasi Pengabdian kepada Masyarakat, metode yang diterapkan mengacu pada pola penalaran induktif. Strategi pengabdian kepada masyarakat yang diterapkan mengacu pada strategi penelitian aksi yang bermula dari kesadaran peneliti untuk menjadi bagian dari warga Desa Pengkol yang menghadapi masalah dalam mengelola dan mengembangkan Desa Wisata Pengkol. Selanjutnya, peneliti menawarkan konsep tentang pencitraan dan promosi agar desa wisata dikenal oleh masyarakat luas. Peneliti kemudian mencoba untuk mendeskripsikan dan menjelaskan konsep yang ditawarkan kepada warga desa. Melalui proses pembelajaran bersama, konsep tersebut direlefeksikan, disepakati, diterapkan, dievaluasi, dan dimodifikasi sehingga menghasilkan konsep baru yang bermanfaat, baik bagi peneliti maupun warga desa (McNiff dan Whitehead, 2006:7-15; Veal, 2006:103-104; Kindon dkk., 2007:9-18; Levent dkk., 2008:80—81; Klein, 2012:1—10).

\section{Pelaksanaan Program}

Pelaksanaan strategi pengabdian kepada masyarakat pencitraan dan promosi Desa Wisata Pengkol yang berbasis penellitian aksi terdiri atas berbagai tahapan sebagai berikut.

\section{Tabap 1}

Diskusi kelompok terpumpun/FGD (focus group discussion) yang berbentuk workshop mengawali pelaksanaan kegiatan pengabdian kepada masyarakat tahap 1 di Desa Pengkol. Peserta kegiatan ini terdiri atas pemprakarsa pengabdian kepada masyarakat dan pemangku kepentingan (stakeholder) Desa Wisata Pengkol, yaitu pengurus dan anggota Pokdarwis Desa Pengkol, Pengurus kelurahan desa wisata, perwakilan pengelola Bendung Colo, perwakilan Dinas Kebudayaan Sukoharjo, serta warga Desa Pengkol yang berminat mengikuti diskusi ini. Merebaknya pandemi Covid-19 mengakibatkan 


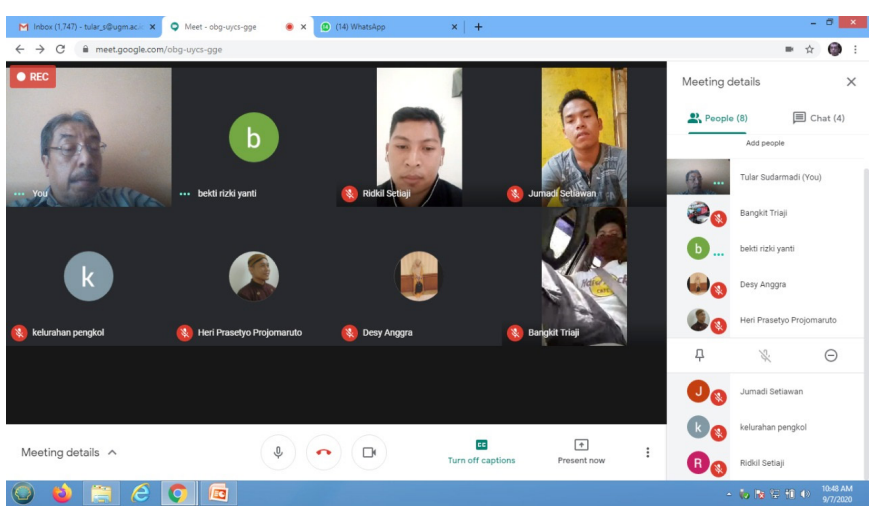

Gambar 3. Kegiatan tahap 1 workshop dengan para pemangku kepentingan Desa Wisata Pengkol Sumber: dokumentasi pribadi

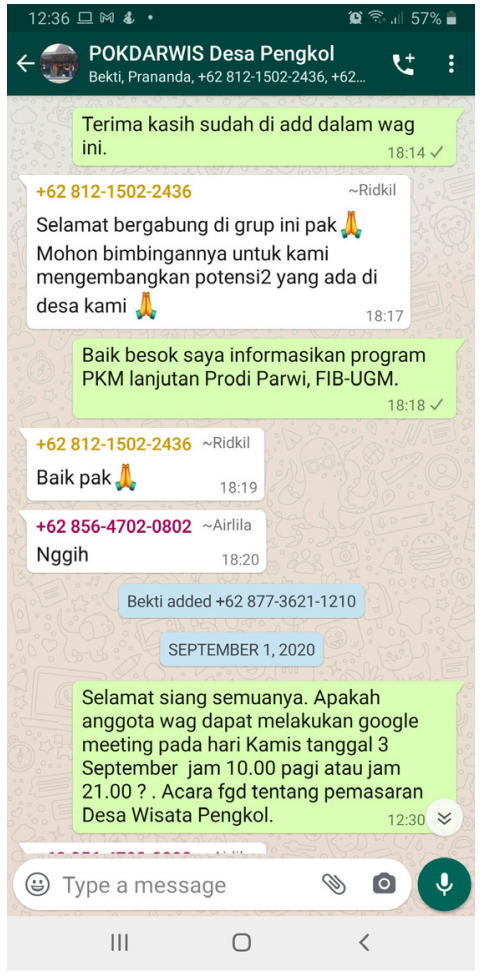

Gambar 4. WhatsApp grup untuk komunikasi kegiatan pengabdian kepada masyarakat. Sumber: dokumentasi pribadi

kegiatan tersebut dilakukan secara online dengan menggunakan media Google Meet. Sebanyak 15 orang peserta yang merupakan representasi para pemangku kepentingan berpartisipasi dalam pertemuan yang dilaksanakan dari jam sembilan pagi hingga jam satu siang. Meskipun demikian, kendala sinyal dan kesibukan pekerjaan mengakibatkan hanya 10 orang yang kehadirannya berkelanjutan dari awal hingga akhir acara.

Melalui forum ini, pemprakarsa kegiatan pengabdian kepada masyarakat menyampaikan gagasan tentang apa, bagaimana, dan mengapa pencitraan serta promosi penting dilakukan dalam pemasaran produk Desa Wisata Pengkol. Pemprakarsa kemudian melakukan refleksi terhadap informasi yang diberikan dan memohon tanggapan kepada seluruh peserta. Selanjutnya, moderator yang merupakan mahasiswa dari Program Studi Pariwisata memandu sesi kedua untuk mengetahui gagasan awal para peserta diskusi tentang impian atau keinginan mereka dalam merepresentasikan pencitraan karakter atau identitas produk Desa Wisata Pengkol. Objek atraksi wisata yang akan mereka pilih dicatat dan didaftar untuk pembuatan video pencitraan Desa Wisata Pengkol. Selama sesi ini, moderator memediasi jika terjadi perbedaan persepsi, pertanyaan, dan usulan tentang pencitraan produk Desa Wisata Pengkol. Setelah rehat untuk makan siang dan sholat, diskusi dilanjutkan untuk menyepakati dan menjadwalkan kegiatan pengambilan gambar video (video shooting). Pada sesi ketiga ini, peserta diskusi secara aklamasi menunjuk pemprakarsa menjadi pendamping, pembuat naskah pembuatan video, dan penyunting hasil pengambilan gambar video. Pokdarwis Desa Wisata Pengkol 
juga menyanggupi untuk melaksanakan kegiatan pengambilan gambar video. Berkaitan dengan jadwal kegiatan, para peserta diskusi kelompok terpumpun sepakat melakukan kegiatan pengambilan gambar pada awal Oktober. Selain itu, disepakati pula untuk membuat WhatsApp grup Pokdarwis Desa Wisata Pengkol sebagai sarana komunikasi, baik selama pelaksanaan program Pengabdian kepada Masyarakat tahun ini maupun keberlanjutannya di tahun-tahun berikutnya (periksa foto 2).

\section{Tabap 2}

Sesuai dengan gagasan pemprakarsa, akan diselenggarakan workshop kedua tentang proses pembuatan video, teknik pengambilan gambar, dan editing. Meskipun demikian, setelah didiskusikan melalui WhatsApp grup Pokdarwis Desa Wisata Pengkol, workshop ini tidak perlu dilakukan. Hal ini karena pihak Pokdarwis dan warga desa sudah banyak yang memiliki keterampilan dalam pembuatan video, bahkan dapat merekomendasikan karya video campur sari dari artis Desa Pengkol bernama Pop Heri Gempil yang merupakan warga asli Desa Pengkol (dapat disaksikan pada link ini https://www. youtube.com/watch?v=4rHVYWZsjjk).

Pemprakarsa juga menawarkan untuk mengganti workshop dengan tema lain, yaitu

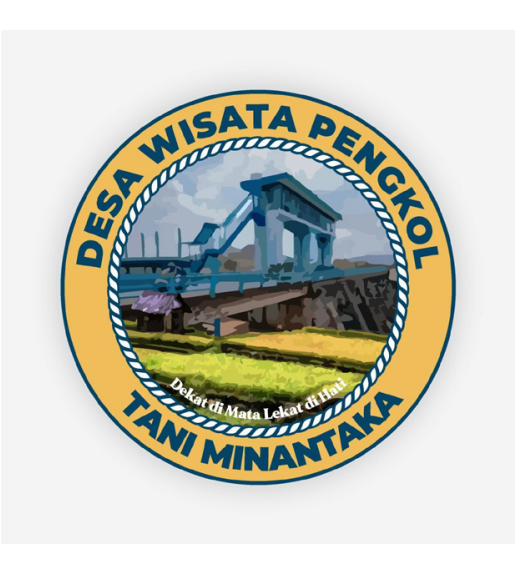

Gambar 5. Logo Desa Wisata Pengkol dengan jargon "Dekat di Mata Lekat di Hati". Sumber: arsip pribadi pembuatan naskah dan narasi atraksi wisata yang ada di Desa Wisata Pengkol, tetapi pengurus dan anggota Pokdarwis menyarankan untuk dilakukan pada kesempatan yang lain. Sementara ini, mereka ingin pemprakarsa yang membuat naskah pencitraan dan promosi sehingga tahap ini dialihkan untuk mendiskusikan naskah serta logo Desa Wisata Pengkol.

Gagasan logo beridentitas warisan budaya Desa Pengkol, yaitu desa yang didominasi dan diwarnai kehidupan petani serta aktivitas nelayan di Bengawan Solo sudah disampaikan oleh pemprakarsa pada workshop sebelumnya. Pada waktu itu, mereka menerima dan menyetujui identitas Desa Pengkol dengan jargon "Desa Wisata Pengkol Tani Minantaka' (diambil dari Bahasa Jawa Kuno yang berarti petani dan nelayan)”. Pada tahap ini, jargon tersebut akan direpresentasikan dalam bentuk visual semacam logo. Sesudah berdiskusi melalui grup WhatsApp, akhirnya berhasil disepakati logo yang sesuai dengan warna, bentuk, dan lambang yang diinginkan warga.

\section{Naskah Pencitraan Desa Wisata Pengkol}

Selanjutnya, pemprakarsa mengajukan naskah (script) untuk pembuatan gambar video pencitraan Desa Wisata Pengkol “Tani Minanataka” dengan jargon "Dekat di Mata Dekat di Hati” kepada pengurus dan anggota Pokdarwis Desa Wisata Pengkol sebagai berikut.

\section{Skenario 1}

Sebuah mobil berhenti di Bendungan Colo. Penumpang mobil yang teridiri atas satu 
keluarga (3-6 orang, terdiri atas ayah, ibu, dan anak) keluar dari mobil kemudian menikmati pemandangan dan berswafoto saat matahari terbenam. Properti yang diperlukan meliputi video/kamera, tripod, mobil (yang umum dipakai oleh keluarga Indonesia), kamera, ponsel, pakaian, aksesoris (topi, kacamata, tas, dan seterusnya), pemeran 1 orang ayah, 1 orang ibu, 2 orang anak, 1 orang kakek, dan 1 orang nenek.

\section{Skenario 2}

Saat mereka akan mengakhiri kegiatan swafoto, datang seorang warga Pengkol mengendarai sepeda motor yang menjemput dan akan mengantar ke homestay. Mereka kemudian bersama-sama berangkat ke homestay. Sepanjang jalan, mereka bertemu dengan rombongan angon sapi, kambing, dan itik. Sampai di homestay, mereka dipersilakan masuk dengan penyambutan yang ramah. Properti yang diperlukan antara lain sepeda motor, pakaian warga lokal penjemput, pakaian penggembala, caping, cemeti, sapi, kambing, dan itik. Cari lokasi yang menarik saat perjumpaan dengan penggembala, 1 homestay, perlengkapan ruang tamu, dan kamar homestay. Pemeran terdiri atas $1-2$ orang penjemput (suami dan istri) dan 3 orang penggembala.

\section{Skenario 3}

Pagi hari, mereka berwisata di Desa Pengkol dengan menaiki sepeda dan diantar pemandu wisata melihat objek atraksi wisata pertanian, menangkap ikan, mencoba ikut bertani, dan menangkap ikan. Properti yang diperlukan antara lain sepeda sejumlah 4-7, pakaian berwisata untuk keluarga yang menginap, pakaian untuk pemandu wisata, pakaian untuk petani, peralatan bertani, pakaian untuk penangkap ikan, dan peralatan menangkap ikan. Ikan hasil tangkapan yang sudah ada sebelumnya.

\section{Skenario 4}

Keluarga yang menginap di homestay berpamitan, kemudian diantar penjemput menaiki sepeda motor, bertemu dengan beberapa petani yang bersiap-siap pulang ke rumah, dan mengucapkan selamat tinggal serta melambai-lambaikan tangan di lokasi tempat persawahan yang menjadi sarang burung bangau serta pemandangan matahari terbenam yang ada bukit seperti orang tidur serta semacam pagoda. Properti yang diperlukan antara lain mobil, sepeda motor, pakaian keluarga yang berwisata, pakaian pemilik homestay, dan pakaian pengantar pulang serta peralatan pertanian. Pemeran terdiri atas 1 orang ayah, 1 orang ibu, 2 orang anak, 1 orang kakek, 1 orang nenek, serta pengantar (1 orang suami dan 1 orang istri) dan beberapa petani. Hasil shooting video masih harus diedit sehingga waktu tayang menjadi $1-2,5$ menit.

\section{Naskah Promosi Desa Wisata Pengkol}

Video naskah promosi Desa Wisata Pengkol dibuat sedikit lebih panjang daripada video pencitraan Desa Wisata Pengkol. Hal ini karena video promosi akan memberikan representasi virtual yang menjelaskan di mana, apa, kapan, bagaimana, dan mengapa desa tersebut pantas untuk dikunjungi sebagai atraksi wisata. Berikut naskah promosi Desa Wisata Pengkol.

\section{Skenario 1}

Desa Pengkol dapat dicapai dari tiga arah mata angin. Jalur utara melalui jalan raya Kotamadya Solo menuju jalan Kabupaten Sukoharjo kemudian masuk ke Desa Pengkol. 
Jalur selatan melalui jalan Kabupaten Wonogiri kemudian masuk ke Desa Pengkol. Jalur barat dari jalan Kabupaten Klaten kemudian masuk ke Desa Pengkol. Angkutan umum yang tersedia untuk menuju Desa Pengkol ialah bus umum, ojek, dan kereta api. Titik pemberhentian bus untuk menuju Desa Pengkol ialah Terminal Bus Tirtonadi, Solo. Selanjutnya, perjalanan dilanjutkan dengan naik ojek atau bus antardesa jurusan Solo-Nguter. Untuk mencapai Desa Pengkol, para wisatawan (dari seluruh wilayah Jawa) harus turun di Stasiun Balapan, Solo. Selanjutnya, mereka melanjutkan perjalanan dengan kereta api jurusan Solo-Wonogiri dan berhenti di Stasiun Nguter.

\section{Skenario 2}

Visualisasi pendukung peta, shoot tugu masuk Kabupaten Sukoharjo, shoot gerbang masuk Desa Pengkol, shoot bagian depan Terminal Bus Tirtonadi, shoot bagian depan terminal, bus yang menuju ke Desa Pengkol, shoot Stasiun Balapan, shoot KA Solo-Wonogiri, shoot Stasiun Nguter. Selanjutnya, berupa narasi sejarah asal mula Desa Pengkol. Sekitar tahun 1965-an, Desa Pengkol terletak di kelokan Sungai Bengawan Solo dan akibat banjir besar yang melanda desanya, pemerintah kemudian memindahkan penduduk Desa Pengkol ke tempat desa baru sekarang ini. Di lokasi wilayah baru tersebut, juga dihuni oleh warga desa pindahan dari Desa Bangunsari dan Desa Pending. Meskipun mereka bersedia pindah ke lokasi yang baru, tetapi saat mereka bermufakat dengan kedua warga dukuh pindahan lainnya, warga Desa Pengkol yang paling banyak jumlah warganya bersikeras tetap mempertahankan nama desa "Pengkol" yang berarti desa di kelokan atau tikungan Sungai Bengawan Solo. Nama baru desa pindahan tersebut (bedhol deso) kemudian disepakati oleh seluruh warga desa yang bermufakat dan sampai saat ini, nama tersebut tetap lestari. Salah satu hal yang menarik, meskipun desa baru ini tidak lagi terletak di pinggir Bengawan Solo, para tetua adat, sesepuh desa, dan para orang tua tetap melestarikan tradisi untuk menjadikan generasi muda mereka sebagai nelayan dengan cara menangkap ikan di Bendung Colo dan menyekolahkan anaknya di Program Studi Pelayaran, Pariwasata untuk kemudian bekerja di kapal pesiar setelah menyelesaikan pendidikannya.

\section{Skenario 3}

Visualisasi pendukung, shooting yoni di Desa Pengkol, shooting lingga di depan kantor polisi, shooting lokasi awal di kelokan Sungai Bengawan Solo, shooting wawancara dengan tokoh adat, tetua desa di lokasi yoni, shooting wawancara dengan tokoh adat, kepala desa, tetua desa, tokoh masyarakat di lokasi-lokasi yang dapat menunjukkan sejarah asal mula Desa Pengkol, shooting sekolah pelayaran dan Pariwisata, mencari foto wisuda, mencari foto ijazah, mencari foto pekerja kapal pesiar Desa Pengkol di depan kapal pesiarnya. Aktivitas keseharian warga Desa Pengkol. Saat ini, jumlah penduduk Desa Pengkol pria sebanyak 2.055 orang dan wanita sebanyak 1.894 orang. Sebagian besar mereka bekerja sebagai petani, buruh tani, dan sebagian lainnya bekerja sebagai pegawai negeri sipil, TNI/Polri, buruh industri, dan pedagang. Pendidikan sebagian besar warga desa baru mencapai tingkat sekolah dasar dan sekolah menengah pertama, hanya sebagian kecil yang menyelesaikan pendidikan hingga perguruan tinggi. Pada umumnya, pemuda Desa Pengkol mengembara ke kota-kota besar dan mencari lapangan pekerjaan informal antara lain sebagai penjual bakso, mi ayam, dan sebagai pembantu rumah tangga. Visualisasi pendukung berupa aktivitas PNS di Kelurahan Pengkol, shooting aktivitas 
bertani, menangkap ikan, menggembala ternak, foto-foto pekerja kapal pesiar, serta penjual bakso dan mi ayam di luar Pengkol (kabupaten, provinsi).

\section{Skenario 4}

Atraksi wisata Desa Pengkol meliputi Bendung Dam Colo, persawahan, pemandangan dan aktivitas sepanjang saluran air Bendung Colo, pembuatan jaring dan alat penciduk ikan, ikut merasakan aktivitas bertani, menangkap ikan, pemandangan saat matahari terbenam di Bendung Colo, persawahan, ladang, tari-tarian, upacara adat, dan rumahrumah khas Desa Pengkol disorot oleh kamera. Visualisasi pendukung video atraksi wisata dipilih di lokasi terbaik, terindah, dan instagramable. Ketersediaan sarana dan fasilitas publik (amenitas) sebagai pendukung keberhasilan Desa Wisata Pengkol sebagai objek daya tarik wisata juga disorot, meliputi listrik, air bersih, telekomunikasi, pasar, mini market, pertokoan, bank, café, warung makan, ATM, homestay, tempat peribadatan, rumah sakit, kantor polisi, kantor Koramil, dan sepeda yang dapat disewakan kepada wisatawan. Visualisasi pendukung berupa shooting gardu, tiang listrik, kabel listrik di jalan, permukiman desa, air bersih, tower komunikasi, gedung bank, ATM, homestay, fasilitas kamar tamu, ruang tidur, toilet, warung makan, shooting kafe bagian dalam, menu khas, shooting makanannya, sertifikat kebersihan, shooting tempat peribadatan, fasilitasnya, shooting kantor kelurahan, polisi, Koramil (bagian dalam gedung, aktivitas kegiatan kantor), shooting rumah sakit, dan shooting sepeda.

\section{Proses Pembuatan Video Pencitraan dan Promosi Desa Wisata Pengkol}

Naskah video pencitraan dan Promosi Desa Wisata Pengkol yang sudah didiskusikan kemudian dipakai sebagai acuan dalam pengambilan gambar video. Semua properti dan pemain disiapkan oleh pengurus serta anggota Pokdarwis Desa Wisata Pengkol. Lokasi pengambilan gambar video dikoordinasikan dengan pemilik mobil, sepeda, sepeda motor, dan homestay. Semua kegiatan bersifat swadaya dan melibatkan peran serta semua pemangku kepentingan Desa Wisata Pengkol. Pemprakarsa bertindak sebagai pendamping dan memfasilitasi penyewaan kamera video. Hal ini disebabkan oleh adanya jadwal pengambilan gambar video yang dilakukan pada saat yang bersamaan, tetapi di lokasi yang berbeda. Satu hal yang tidak dapat dilakukan oleh pemprakarsa pada saat pendampingan pengambilan gambar video ialah larangan untuk mengunjungi Desa Pengkol. Saat itu, Kecamatan Nguter tidak mengizinkan masyarakat luar untuk memasuki kawasannya karena wabah Covid-19 sedang dalam puncak penyebaran di hampir seluruh desa di Kecamatan Nguter, termasuk Desa Pengkol. Akibatnya, secara terpaksa dilakukan beberapa perubahan skenario, termasuk di antaranya hilangnya peran anak-anak dan orang tua karena tidak diperbolehkan oleh perangkat desa untuk keluar dan beraktivitas di sekitar Desa Pengkol. Penundaan beberapa skenario karena wabah Covid-19 juga berakibat pada pergantian jenis-jenis tanaman dari musim hujan memasuki musim kemarau, penurunan ketinggian dan debit air, serta berkurangnya berbagai aktivitas menanam padi di sawah. Kondisi ini tentu saja menyulitkan proses shooting untuk video promosi yang lebih kompleks skenarionya, tetapi untuk pengambilan gambar video pencitraan pengaruhnya tidak terasa sama sekali.

Seluruh kesulitan yang muncul tidak terasa memberatkan karena kerja sama dan koordinasi yang baik antara seluruh tim pengurus dan anggota Pokdarwis (hampir 


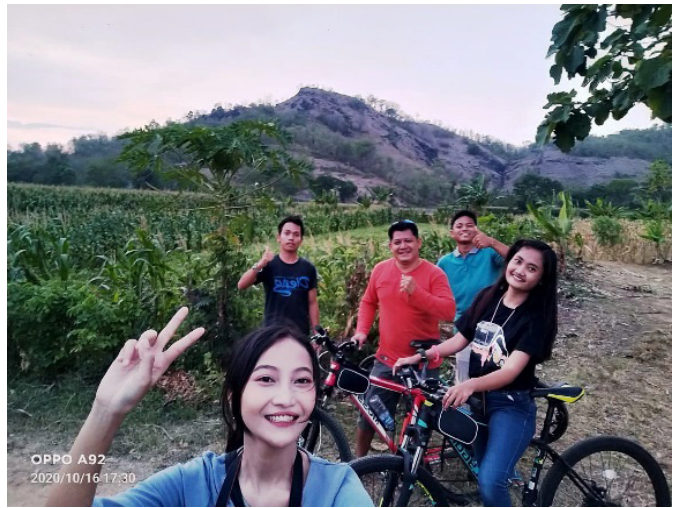

Gambar 6. Persiapan pengambilan gambar video bersepeda keliling Desa Pengkol. Sumber: dokumentasi pribadi

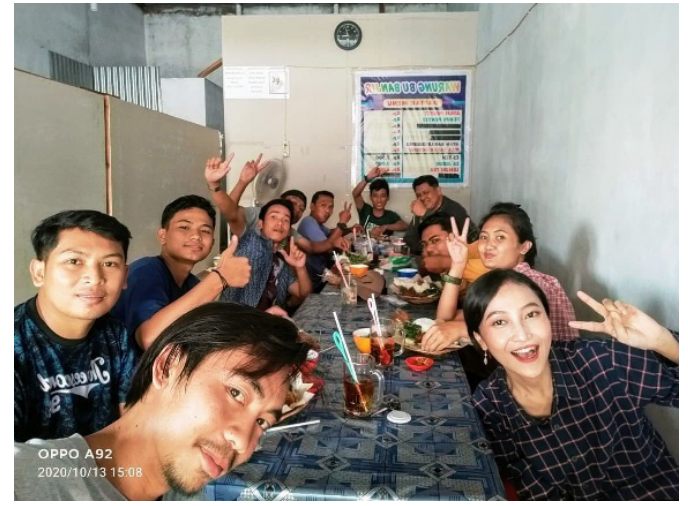

Gambar 7. Setelah proses pengambilan gambar dan video. Sumber: dokumentasi pribadi

seluruhnya terlibat), para pemangku kepentingan, serta pemprakarsa. Keharusan untuk menambah dan mengulangi pengambilan gambar video tidak pernah menyebabkan terjadinya konflik yang berkepanjangan. Beberapa kegiatan pengambilan gambar video dapat dilihat pada Gambar 6 dan Gambar 7.

Satu hal yang perlu diapresiasi dan disyukuri ialah bagaimanapun hasilnya, pengambilan gambar video beserta proses pengeditannya berhasil diselesaikan sesuai dengan agenda kerja, semua personal yang terlibat tidak ada satupun yang terpapar Covid-19, dan koordinasi serta kerja sama selama proses pelaksanaan berjalan dengan lancar dan sukses serta benar-benar merefleksikan keberhasilan metode penelitian aksi yang ditransformasikan dalam program kegiatan pengabdian kepada masyarakat tahap ketiga di Desa Wisata Pengkol.

\section{Refleksi Capaian Program}

Sesuai dengan capaian sasaran pada program pengabdian kepada masyarakat di Desa Wisata Pengkol tahap ketiga, yaitu pembuatan video pencitraan dan promosi desa wisata tersebut, akhirnya dapat diselesaikan logo pencitraan dan pembuatan kedua videonya. Tahap selanjutanya logo tersebut akan dijadikan sebagai tampilan profil Desa Wisata Pengkol yang diupload bersama-sama dengan video pencitraan dan promosi. Selanjutnya, video pencitraan (branding) dapat diakses melalui link YouTube https://youtube.com/ watch? $v=$ py-315ql1p0\&feature=share, sedangkan video promosi dapat diakses melalui link YouTube https://youtube.com/watch?v=97mEp8ARmRw\&feature=share. Selain itu, promosi Desa Wisata Pengkol juga dapat diakses melalui link Instagram https://www. instagram.com/tv/Clzz5JRDOqG/?utm medium=copy link. Kemudian, salah satu hingga tiga anggota Pokdarwis Desa Wisata Pengkol dijadikan sebagai administrator untuk mengelola media sosial yang dijadikan sebagai media promosi dan pemasaran Desa Wisata Pengkol. Alamat e-mail Desa Wisata Pengkol ialah pengkol.desawisata@ gmail.com.

Program pengabdian masyarakat di Desa Pengkol merupakan program pariwisata berbasis masyarakat yang akan dilakukan secara berkelanjutan di Desa Pengkol. Program 
Studi Pariwisata berketetapan untuk menjadikan desa tersebut sebagai 'laboratorium' yang dapat dipergunakan sebagai lokasi praktik mata kuliah Program Studi Pariwisata yang berkaitan dengan minat atraksi wisata dan destinasi wisata. Selaras dengan tujuan tersebut, Program Studi Pariwisata sudah merancang program kelanjutan pengabdian masyarakat jangka menengah berupa perancangan dan pembuatan program paket wisata dan program pemasaran yang diawali dengan pencitraan (branding) dan promosi Desa Wisata Pengkol dan akan diteruskan melalui kerja sama dengan Dinas Kebudayaan untuk memasukkan program karya wisata berkunjung ke Desa Wisata Pengkol bagi sekolah setingkat pendidikan dasar dan menengah, biro agen perjalanan dan hotel yang menjadi mitra Program Studi Pariwisata, Fakultas Ilmu Budaya, Universitas Gadjah Mada, serta instansi Dinas Pariwisata di Provinsi Jawa Tengah. Progam jangka menengah ini direncanakan selama satu tahun. Tahap akhir jangka panjang dari program pengabdian di Desa Wisata Pengkol berupa pendampingan serta selama tahun terakhir melakukan evaluasi terhadap program paket wisata dan mengetahui tingkat kepuasan para wisatawan yang mengunjungi Desa Wisata Pengkol. Program evaluasi merupakan rencana jangka panjang dari program pengabdian di Desa Pengkol.

\section{Penutup}

Pengabdian masyarakat di Desa Pengkol, Kecamatan Nguter, Kabupaten Sukoharjo, Jawa Tengah merupakan upaya para dosen di Fakultas Ilmu Budaya untuk menerapkan keahlian ilmunya kepada warga Desa Pengkol. Melalui serangkaian program yang berkelanjutan, diharapkan masyarakat setempat mampu menyerap ilmu yang dipraktikkan sehingga dapat membantu masyarakat untuk meningkatkan kesejahteraan mereka. Pengabdian masyarakat ini bersifat lintas ilmu dan multidisipliner serta melibatkan partisipasi masyarakat sejak awal hingga akhir kegiatan. Tentu saja pengabdian masyarakat ini tidak semata-mata bersifat nonakademik, tetapi setiap program pemberdayaan masyarakat berlandaskan pada teori-teori dan paradigma yang sedang menjadi tren di ilmu-ilmu sosial humaniora, khususnya ilmu pariwisata. Di masa selanjutnya, diharapkan program pengabdian masyarakat merupakan kegiatan yang memiliki pelayanan sekaligus studi yang berlandaskan pada asas-asas penelitian. Hal ini akan mendorong perumusan teoriteori baru yang dihasilkan dari praktik di lapangan, khususnya yang berupa program pengabdian masyarakat.

\section{Daftar Pustaka}

Armstrong, dkk. (2017). Marketing an Introduction. New Jersey: Pearson Education, Ltd.

Beeton, Sue. (2006). Community Development Through Tourism. Collingwood: Landlink Press.

Cooke, Mike dan Buckley, Nick. (2008). 'Web 2.0, Social Networks and the Future of Market Research'. International Journal of Market Research, Vol. 50, No. 2. hlm. 267-292.

Jamal, Tazim dan Dredge, Dianne. (2015). 'Tourism and Community Development Issues'. (Ed.) Richard Sharpley dan David J. Telfer. Tourism and Development. 
Concepts and Issues $2^{\text {nd }}$ Edition. Bristol: Channel View Publication. hlm. 178-204. Kindon, Sara, Pain Rachel, dan Kesby, Mike. (2007). 'Participatory Action Research: Origins, Approaches, and Methods'. (Ed.) Kindon, Sara, Pain Rachel, dan Kesby, Mike. Participation Action Research, Approaches, and Methods: Connecting People, Participation and Place. New York: Routledge. hlm. 9-18.

Klein, Sheril L., ed. (2012). 'Action Research: Before You Dive in Read This !. (Ed.) Klein, Sheril L. Action Research Methods: Plain and Simple. New York: Palgrave Macmillan. hlm. 1- 20.

Levent, Altinay dan Paraskevas, Alexandros. (2008). Planning research in Hospitality and Tourism. Oxford: Elsevier, Ltd.

Kotler, Philip dan Kettler Kevine L. (2016). Marketing Management 15. Uttar Pradesh: Pearson India Education Services, Pvt. Ltd.

McNiff, Jean dan Whitehead, Jack. (2006). All You Need to Know about Action Research: An Introduction. London: Sage Publications, Ltd.

Minazzi, Roberta. (2015). Social Media Marketing in Tourism and Hospitality. London: Springer International Publishing.

Morgan, Nigel, Pritchard, Annette dan Pride Roger. (2004). 'Introduction'. (Ed.) Morgan, Nigel, Pritchard, Annette dan Pride Roger. Destination Branding: Creating the Unique Destination Proposition. Oxford: Elsevier, Ltd. hlm. 3-16.

Ohe, Yasou. (2020). Community-Based Rural Tourism and Entrepreneurship: A Microeconomic Approach. Singapore: Springer.

Pike, Steven. (2004). Destination Marketing Organization. Amsterdam: Elsevier, Ltd. (2008). Destination Marketing: An Integrated Marketing Communication Approach. Oxford: Elsevier, Ltd.

Scheyvens, Regina. (2015). 'Tourism and Poverty Reduction'. (Ed.) Richard, Sharpley dan David J. Telfer. Tourism and Development. Concepts and Issues $2^{\text {nd }}$ Edition. Bristol: Channel View Publication. hlm. 118-138.

Sigala, Marriana. (2012). 'Introduction'. (Ed.) Sigala, Mariana, Christou, Evangelos, dan Gretzel Ulrike. Social Media in Travel, Tourism, and Hospitality: Theory, Practice and Cases. Surrey: Ashgate Publishing Limited. hlm. 7-10.

Suansri, Potjana. (2003). Community Based Tourism: Handbook. Thailand: Responsible Ecological Social Tour.

Sudarmadi, Tular. (2018). 'Pengembangan Potensi Kepariwisataan Berbasis Masyarakat di Desa Pengkol, Kabupaten Sukoharjo, Jawa Tengah'. Jurnal Bakti Budaya. Vol. 1, No. 1. hlm. 73-91.

Tasci, Asli D.A. (2011). 'Destination, Branding, and Positioning'. (Ed.) Wang, Youcheng dan Pizam, Abraham. Destination Marketing and Management: Theories and Applications. Cambridge: CABI. hlm.113-129.

The Mountain Institute. (2000). Community Based Tourism for Conservation and Development: A Resource Kit. Washington D.C.

Veal, A.J. (2006). Research Methods for Leisure and Tourism: A Practical Guide. Harlow: Pearson Education Limited.

Yanti, Bekti Rizki. (2020). 'Pembentukan Organisasi Pariwisata Berbasis Masyarakat di Desa Pengkol, Sukoharjo, Jawa Tengah”. Skripsi. Program Studi Pariwisata, Fakultas Ilmu Budaya, Universitas Gadjah mada, Yogyakarta. 